\title{
X-linked hypophosphatemia with enthesopathy
}

\author{
Rimesh Pal, Anil Bhansali
}

Department of Endocrinology, Post Graduate Institute of Medical Education and Research, Chandigarh, India

\section{Correspondence to} Dr Anil Bhansali, anilbhansaliendocrine@gm ail.com

Accepted 25 July 2017

\section{DESCRIPTION}

A 42-year-old man presented with lower limb bowing since childhood along with low backache and proximal muscle weakness for 8 years. He had strong family history of similar complaints in his elder brother, younger sister and daughter. Examination revealed loss of teeth and genu varum. Investigations showed corrected serum calcium of $8.9 \mathrm{mg} / \mathrm{dL}$, phosphate $1.5 \mathrm{mg} / \mathrm{dL}$, intact parathyroid hormone (iPTH) $47 \mathrm{pg} / \mathrm{mL}$ and $25(\mathrm{OH})$ vitamin D $32.7 \mathrm{ng} / \mathrm{mL}$. He had phosphaturia with TmP/GFR (ratio of renal tubular maximum reabsorption of phosphate to the glomerular filtration rate) of $0.4 \mathrm{mmol} / \mathrm{L}$ (range 0.89 $1.34 \mathrm{mmol} / \mathrm{L}$ ). His serum FGF-23 fibroblast growth factor 23 (FGF-23) was 89 RU/ml (range 0-150 RU/ $\mathrm{ml}$ ). Workup of the affected family members also revealed hypophosphatemia with phosphaturia. Radiograph showed calcification of sacrospinous ligaments, tensor fascia latae (figure 1) and right biceps brachii tendon (figure 2) suggestive of enthesopathy. In addition, there was bowing, 'beaking' and lateral cortical fractures of both femur (figure 1). In view of hypophosphatemia, phosphaturia, strong family history and radiological evidence of enthesopathy, he was diagnosed as X-linked dominant hypophosphatemic rickets (XLH). He was commenced on oral phosphate and calcitriol supplementation with marked improvement in symptoms.

Enthesopathy refers to involvement of the entheses in any pathological process. XLH is one of the

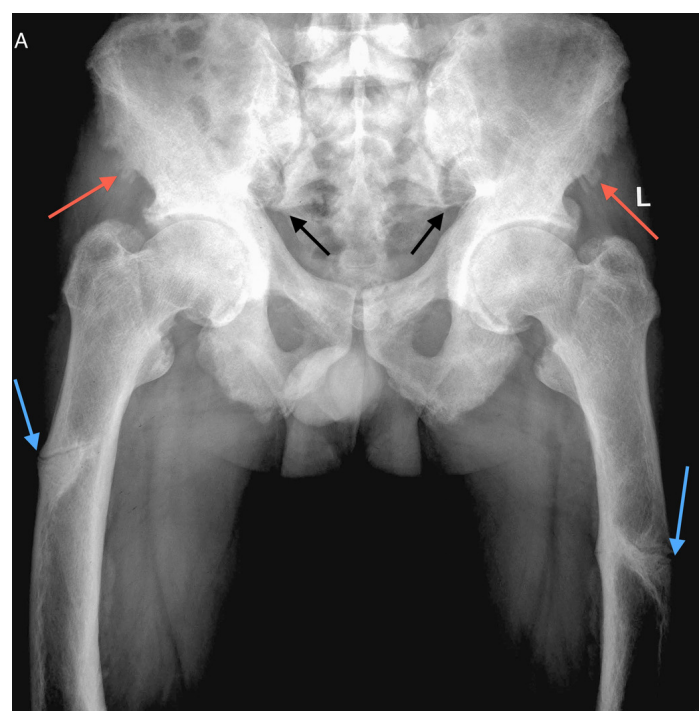

Figure 1 Anteroposterior radiograph of pelvis showing calcifications of sacrospinous ligaments (marked in black arrows), tensor fascia latae (marked in red arrows) along with bowing, 'beaking' and lateral cortical fractures of both femur (marked in blue arrows).

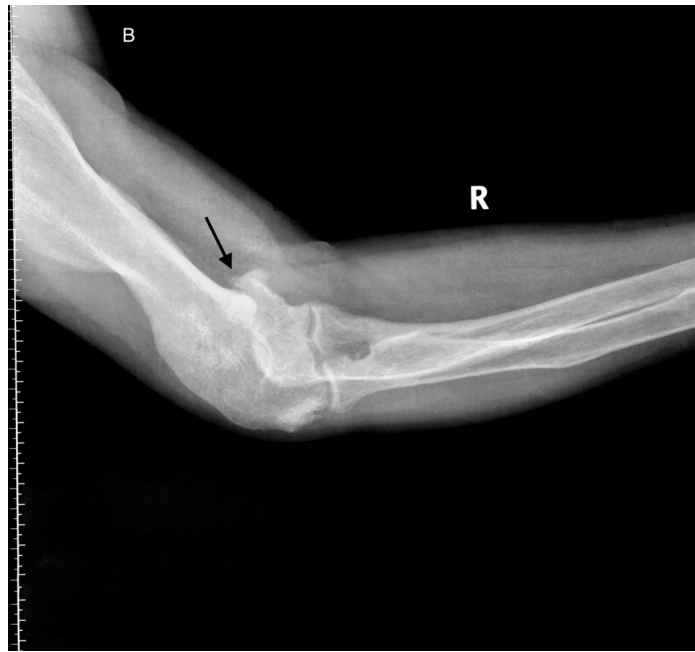

Figure 2 Lateral radiograph of right elbow showing calcification of the right biceps brachii tendon (marked in black arrow).

well-recognised causes of enthesopathy. With an incidence of 1:20000 live births, XLH is the most common cause of heritable rickets. Patients with XLH usually complain of bone pain, proximal myopathy and bony deformities, consistent with rickets/osteomalacia. Serum FGF-23 levels are usually elevated, however, may be inappropriately normal for the degree of hypophosphatemia, as was in our patient. Treatment consists of phosphate and calcitriol supplementation. Bone pains and proximal muscle weakness improve significantly; however, longitudinal growth in children remains unsatisfactory ${ }^{1}$. Enthesopathy in XLH develops late in the course of the disease and is probably a result of increased FGF-23 activity in the presence of excess periarticular chondroitin sulfate ${ }^{2}$. Conventional treatment does not affect enthesopathy ${ }^{3}$.

\section{Learning points}

- X-linked hypophosphatemia (XLH) is the most common cause of heritable rickets.

- Enthesopathy is a characteristic feature of XLH; however, it can be seen in other metabolic, inflammatory and degenerative disorders.

- Treatment with phosphate and active vitamin D supplements improves osteomalacia, but has little or no effect on linear growth and enthesopathy. include Day Month Year] doi:10.1136/bcr-2017-

220920 
Contributors RP prepared the manuscript. AB provided overall guidance.

Competing interests None declared.

Patient consent Obtained.

Provenance and peer review Not commissioned; externally peer reviewed.

(c) BMJ Publishing Group Ltd (unless otherwise stated in the text of the article) 2017. All rights reserved. No commercial use is permitted unless otherwise expressly granted.

\section{REFERENCES}

1 Fuente R, Gil-Peña H, Claramunt-Taberner D, et al. X-linked hypophosphatemia and growth. Rev Endocr Metab Disord 2017;18:107-15.

2 Yu X, Ibrahimi OA, Goetz R, et al. Analysis of the biochemical mechanisms for the endocrine actions of fibroblast growth factor-23. Endocrinology 2005;146:4647-56.

3 Connor J, Olear EA, Insogna KL, et al. Conventional therapy in adults with X-linked hypophosphatemia: effects on enthesopathy and dental Disease. J Clin Endocrinol Metab 2015;100:3625-32.

Copyright 2017 BMJ Publishing Group. All rights reserved. For permission to reuse any of this content visit http://group.bmj.com/group/rights-licensing/permissions.

BMJ Case Report Fellows may re-use this article for personal use and teaching without any further permission.

Become a Fellow of BMJ Case Reports today and you can:

- Submit as many cases as you like

- Enjoy fast sympathetic peer review and rapid publication of accepted articles

- Access all the published articles

- Re-use any of the published material for personal use and teaching without further permission

For information on Institutional Fellowships contact consortiasales@bmjgroup.com

Visit casereports.bmj.com for more articles like this and to become a Fellow 